\title{
ISKUSTVA MAJKI DJECE S DIJAGNOZOM WILLIAMSOVOG SINDROMA
}

\author{
MARINA MILIĆ BABIĆ ${ }^{1}$, KATARINA JOVIĆ ${ }^{2}$, KSENIJA NAPAN ${ }^{3}$, \\ ${ }^{1}$ Pravni fakultet, Studijski centar socijalnog rada, Zagreb, marina.milic.babic@pravo.hr \\ ${ }^{2}$ mag.soc.rada \\ ${ }^{3}$ School of Social Work, Massey University, New Zealand
}

Primljeno: 14.9.2016.

Prethodno priopćenje

Prihvaćeno: 18.2.2017.

UDK: 364: 616.61-053.2

Sažetak: Williamsov sindrom rijedak je neurorazvojni poremećaj koji ulazi u skupinu rijetkih bolesti. Cilj ovog istraživanja bio je dobiti uvid u iskustvo života i dostupne podrške za djecu koja imaju dijagnozu ove rijetke bolesti iz perspektive roditelja, od koje prema neslužbenim evidencijama boluje 11 osoba u RH. U radu su prikazani rezultati prvog istraživanja u Hrvatskoj u kojem su sudjelovale majke djece s Williamsovim sindromom. Riječje o kvalitativnom istraživanju. Podaci su prikupljeni polustrukturiranim intervjuom, te su analizirani i obrađeni metodom tematske analize. Rezultati istraživanja pokazuju da sudionice imaju iskustvo veće emocionalne povezanosti i bliskosti među članovima obitelji od rođenja djeteta s Williamsovim sindromom, te da imaju podršku od supružnika i drugih članova obitelji i roditelja djece s istom dijagnozom. S druge strane, ova rijetka dijagnoza suočava majke s teškoćama vezanim uz usklađivanje životnih uloga, socijalnom izolacijom i nerazumijevanjem okoline te svakodnevnom skrbi za dijete. Zaključno, rad stavlja u fokus iskustvo života majki čija djeca imaju dijagnozu Williamsovog sindroma. Rezultati daju poticaj roditeljima, oboljelima, praktičarima i znanstvenicima za daljnja istraživanja i praktične mjere koje će unaprijediti mrežu podrške za djecu i odrasle osobe oboljele od rijetkih bolesti.

Ključne riječi: rijetke bolesti, majke, Williams sindrom, podrška

\section{UVOD}

Procjenjuje se da je 25 milijuna Amerikanaca i oko 30 milijuna Europljana pogođeno jednom od $5000-6000$ poznatih rijetkih bolesti, od kojih je većina genetskog podrijetla (Wastfelt i sur., 2006). Prema definiciji prihvaćenoj u EU, u rijetke bolesti spadaju one koje zahvaćaju manje od 5 na 10 000 osoba, što je 1:2 000 (Ministarstvo zdravlja Republike Hrvatske, 2015.), dok se u SAD-u bolest koja utječe na manje od 200000 osoba u zemlji smatra rijetkom (Hughes i sur., 2005). Rijetke bolesti teško se dijagnosticiraju i liječe, a često postoji nedostatak odgovarajućih zdravstvenih usluga, kvalificiranih stručnjaka i učinkovite mogućnosti liječenja i rehabilitacije (Anderson i sur., 2013). Kao posljedica toga značajan je psihosocijalni i emocionalni utjecaj na obitelj i pacijente, a često je situacija složena jer nedostaje odgovarajuća podrška zajednice (Kole i Faurisson, 2009). Williamsov sindrom (WS) rijedak je neurorazvojni poremećaj, čiji je uzrok mikrodelecija nekoliko gena na kromosomu 7 (Mervis i Velleman, 2012). O rijetkosti ovog sindroma govori i pojavnost od 1:10 000 novorođenčadi (Waxler i sur., 2009). U Hrvatskoj je prema neslužbenim informacijama evidentirano 11 oboljelih od WS. Prema podacima iz Hrvatskog registra o osobama s invaliditetom, u Hrvatskoj je ukupno zabilježeno 3118 osoba s rijetkim bolestima (Škes, 2015.). Prvo istraživanje Williamsovog sindroma objavljeno je 1975. godine (Jones i Smith, 1975). Ovaj sindrom karakteriziraju teškoće u učenju i razvoju, neobične karakteristike lica, kardiovaskularne bolesti, neurokognitivne i socijalno bihevioralne abnormalnosti (Mervis i Klein-Tasman, 2000). Značajke koje ukazuju na Williamsov sindrom su promjenjive i mogu se razlikovati prema dobi. Tijekom djetinjstva najčešći su problemi sa srcem i krvnim žilama. Najčešći oblik kardiovaskularnih bolesti koji se javlja kod osoba s Willamsovim 
sindromom je supravalvularna stenoza aorte, što ujedno označava suženje aorte, odnosno suženje krvne žile koja prenosi krv iz srca do ostatka tijela (Waxler i sur., 2009). Ostale zdravstvene teškoće koje se javljaju kod osoba s Williamsovim sindromom su niža porođajna težina i sporo dobivanje na težini, teškoće s hranjenjem koje uzrokuje slab mišićni tonus, jak refleks povraćanja, slabiji refleksi sisanja i gutanja, zubne abnormalnosti, teškoće s funkcioniranjem bubrega (Morris i Mervis, 1999; Ivić i Mravinac, 2005), zatim strabizam, ortopedske teškoće i osjetljivost na zvuk (Donnai i KarmiloffSmith, 2000). Osobe s Williamsovim sindromom obično imaju blage do umjerene intelektualne teškoće. Istraživanja pokazuju da je prosječni IQ osoba s Williamsovim sindromom između 50 i 60 , uz moguć raspon od 40 do 100 (Martens i sur., 2008). Djeca s Williamsovim sindromom imaju dobre jezične sposobnosti (Ivić i Mravinac, 2005), tečno artikuliraju i imaju razvijen i sofisticiran rječnik (Udwin i sur., 2007). Djeca s Williams sindromom prijateljski su nastrojena, otvorena i komunikativna ${ }^{1}$. Iskazuju naklonost prema nepoznatim osobama i starijima, tako da se taj sindrom ponekad i naziva ,cocktail-party syndrome“ (Metcalfe, 1999). Njihova otvorenost najčešće izaziva bojazan kod roditelja jer ne iskazuju strah prema nepoznatome te često ulaze u spontani fizički i verbalni kontakt s nepoznatim osobama (Udwin i sur., 2007).

\section{Obitelji djece s teškoćama u razvoju i socijalna podrška}

Odgoj i podizanje djece predstavljaju svojevrsne izazove za roditelje, no ti izazovi i zahtjevi su još veći kada je riječ o djeci s teškoćama u razvoju, pa se kod roditelja može javiti šok, osjećaj krivnje i samooptuživanja, potiskivanje te projekcija krivnje za stanje djeteta na druge osobe (Leutar i Starčić, 2006; Leutar i sur., 2008). Roditelji najčešće u partnerima pronalaze potporu u skrbi za dijete s teškoćama u razvoju (Milić Babić, 2010), pa tako roditelji koji imaju zajedničke aktivnosti pri obavljanju kućanskih poslova, pri donošenju odluka, te zajedničku rekreaciju, pokazuju nižu razinu stresa od drugih roditelja djece s teškoćama (Lundy, 2011). Formalnu podršku pružaju stručnjaci poput učitelja, socijalnih radnika, zdravstvenih djelatnika, edukacijskih rehabilitatora, logopeda, lokalnih vlasti kroz organizirane usluge i prava u okviru različitih programa i mjera socijalne politike. Neformalnu podršku mogu pružati članovi obitelj, prijatelji, susjedi, drugi roditelji djece s teškoćama u razvoju i kolege na poslu. Dosadašnja istraživanja, usmjerila su se na različite dimenzije neformalne socijalne podrške koja je dostupna obiteljima. Podrška drugih članova obitelji, posebice baka i djedova, može pomoći roditeljima da se bolje nose sa zahtjevima vezanim uz roditeljstvo djeteta s teškoćama u razvoju (White i Hastings, 2004). Naposljetku, roditelji se za podršku obraćaju i vlastitoj djeci (Leutar i Oršulić, 2014), ali i rodbini i prijateljima. Rezultati istraživanja pokazuju pozitivne učinke socijalne podrške poput povećanja osobnih resursa, poboljšanja mentalnog zdravlja, većeg stupnja zadovoljstva obitelji i šire zajednice (Janković, 1995). Roditelji djece koja boluju od rijetkih bolesti najčešće trebaju stručnu podršku liječnika, zatim financijsku pomoć države i podršku drugih roditelja, te im je značajan način na koji su upoznati s dijagnozom djeteta. Nezadovoljstvo i dodatnu težinu opisuju onda kad im je dijagnoza djeteta saopćena na hladan način, putem telefona te im nije ponuđeno individualno savjetovanje i detaljne informacije o bolesti (Anderson i sur., 2013). Živjeti s rijetkom bolešću kao što je Williamsov sindrom i pritom pokušavati voditi normalan život sa svim usponima i padovima, uspjesima i neuspjesima, željama i snovima, snagama i slabostima, uključuje izazove. Unatoč istoj dijagnozi, pojedino dijete, baš kao i obitelji, nose se s dijagnozom svatko na svoj način. Kod pružanja podrške potrebno je voditi se perspektivom da su potrebe obitelji individualno određene i različite za svaku obitelj, dijete i odraslu osobu s rijetkom bolešću.

\section{CILJ I ISTRAŽIVAČKA PITANJA}

Cilj je ovog istraživanja dobiti uvid u iskustva roditelja djece koja imaju dijagnosticiran Williamsov sindrom. U skladu s općim ciljem istraživanja postavljena su slijedeća istraživačka pitanja:

1. Kako roditelji opisuju iskustva $\mathrm{s}$ formalnom $\mathrm{i}$ neformalnom podrškom?

1 Preuzeto s Web stranice Rare diseases: http://rarediseases.org/rare-diseases/williams-syndrome/ (25.5.2016.) 
2. Kako roditelji opisuju život obitelji s rijetkom bolešću?

\section{Sudionici istraživanja}

Ciljna populacija našeg istraživanja su majke djece koja imaju dijagnozu Williamsovog sindroma. Za sudionike smo izabrali majke iz razloga što su, prema dosadašnjim istraživanjima, majke one osobe koje nose glavni teret praktične skrbi o djetetu (Martinac Dorčić, 2008; Milić Babić, 2010). Sudjelovanju u istraživanju odazvale su se majke do kojih smo došli uz pomoć metode snježne grude. Uzorak snježne grude koristi se kada je u uzorku potrebno zahvatiti malu i specifičnu populaciju. Primjena tehnike snježne grude temelji se na početnom odabiru uskog kruga osoba s potrebnim karakteristikama, koje kasnije same šire uzorak (Milas, 2005). Kvalitativna metoda korištena je u ovom istraživanju jer je to najbolja metoda za provođenje istraživanja vezanih uz teme koje su kompleksne, osjetljive i zahtijevaju informacije o osobnom iskustvu sudionika (Ritchie \& Lewis, 2003). Izbor ove metode omogućava istraživaču proučavanje malog broja sudionika, pri čemu se kroz opsežnu analizu i triangulaciju dobivenih podataka omogućava razvoj tema i kategorij te povezivanje i formiranje značenja (Creswell, 2003). U istraživanje su uključene 3 majke čija djeca imaju dijagnozu Williamsovog sindroma. Radi se o teško dostupnoj populaciji te je prema dostupnim neslužbenim statistikama u Hrvatskoj svega 11 osoba s ovom dijagnozom. Prosječna dob sudionica iznosi 38 godina; najmlađa sudionica ima 35 godina, a najstarija 42 godine. Dvije sudionice u stalnom su radnom odnosu, dok se jedna nalazi $\mathrm{u}$ statusu roditelja njegovatelja. Jedna sudionica majka je dvoje djece, dok druge dvije imaju po troje djece. Djeca su u dobi od 5, 7 i 8 godina.

\section{Metoda prikupljanja i analize podataka}

Istraživanje je provedeno u travnju i svibnju 2016. godine putem polustrukturiranog intervjua. Polustrukturirani intervju je intervju u kojem istraživač dopušta sugovorniku manja tematska udaljavanja od postavljenih pitanja (Brinkmann, 2013). Intervjui su u prosjeku trajali sat vremena (56 minuta; 60 minuta; 62 minute), a proveli su ih autori istra- živanja. Sudionice istraživanja dolaze iz različitih regija Hrvatske te zbog etičkih postavki istraživanja koja uključuje punu zaštitu identiteta sudionika i obzirom na iznimnu rijetkost ove dijagnoze nećemo navoditi gradove i županije iz kojih dolaze sudionice istraživanja. Protokol za intervjue sastojao se od 10 otvorenih pitanja kojima se ispituju iskustva roditelja. Podaci su obrađeni, analizirani te interpretirani korištenjem postupaka tematske analize. Za potrebe obrade podataka izradili su se pisani zapisi razgovora iz snimljenih audio zapisa, koji su se podvrgli kvalitativnoj analizi. Analitički proces uključuje pet faza: upoznavanje s građom, definiranje tematskog okvira, indeksiranje (kodiranje), unošenje u tablice, povezivanje i interpretacija (Srivastava i Thomson, 2009; Žižak i sur., 2012). Istraživanje je deskriptivno, a proces istraživanja je induktivan. Interpretacija, kao i zaključci analize poštivali su proces triangulacije (usuglašavanje najmanje tri istraživača) oko relevantnih produkata istraživanja. Istraživanje je temeljeno na filozofskoj poziciji koja je ,interpretativna", na metodama prikupljanja podataka koje su fleksibilne i osjetljive na socijalni kontekst, te metodama analize koje imaju namjeru produbiti razumijevanje područja istraživanja.

\section{REZULTATI I RASPRAVA}

\section{Iskustvo s formalnom i neformalnom podrškom}

U Tablici 1. prikazani su rezultati koji daju odgovor na prvo istraživačko pitanje: „Kako roditelji djece s Williamsovim sindromom opisuju iskustvo formalne i neformalne podrške?"

Sudionice našeg istraživanja kao izvor neformalne podrške navodile su obitelj i prijatelje kao najveći izvor podrške: ,,... jedina podrška bila nam je bliža obitelj i prijatelji... “ (M1); ,,... Moji najbliži, znači roditelji, suprug, moji i njegovi prijatelji... “ (M3). Nalazi Leutar i sur. (2008) pokazuju da roditelji najveću podršku dobivaju od supružnika, a odmah zatim slijede bake i djedovi te prijatelji.

Roditelji druge djece $s$ istom dijagnozom pokazali su se kao važan izvor informacija i korisnih savjeta:

„...A onda sam ja tražila druge roditelje koji imaju dijete s Williamsovim sindromom i tako smo 
Tablica 1. Tematsko područje: Iskustvo s formalnom i neformalnom podrškom

\begin{tabular}{|c|c|}
\hline Teme & Kategorije \\
\hline \multicolumn{2}{|l|}{ NEFORMALNA PODRŠKA } \\
\hline $\begin{array}{l}\text { 1. Obitelj i prijatelji izvor podrške } \\
\text { 2. Podrška roditelja djece s istom dijagnozom }\end{array}$ & $\begin{array}{l}\text { - Podrška obitelji i prijatelja } \\
\text { - Podrška supružnika } \\
\text { - Roditelji druge djece kao izvor informacija i podrške }\end{array}$ \\
\hline \multicolumn{2}{|l|}{ FORMALNA PODRŠKA } \\
\hline $\begin{array}{l}\text { 1. Podrška od strane zdravstvenih djelatnika } \\
\text { 2. Podrška od strane lokalne zajednice } \\
\text { 3. Podrška od strane drugih stručnjaka } \\
\text { 4. Podrška sustava socijalne skrbi }\end{array}$ & $\begin{array}{l}\text { - Zadovoljstvo komunikacijom zdravstvenih djelatnika } \\
\text { - Nejasne informacije o zdravstvenim tegobama djeteta } \\
\text { - Nezadovoljstvo informiranošću zdravstvenih djelatnika o bolesti } \\
\text { - Nezadovoljstvo odnosom zdravstvenih djelatnika prema roditeljima } \\
\text { - Zadovoljstvo lokalnom zajednicom pri integraciji djece u vrtić } \\
\text { - Zadovoljstvo lokalnom zajednicom pri integraciji djece u školu } \\
\text { - Stručna podrška logopeda i defektologa } \\
\text { - Podrška CZSS pri informiranju o pravima } \\
\text { - Nezadovoljstvo profesionalnošću tima za vještačenje }\end{array}$ \\
\hline Podrška neprofitnih organizacija & $\begin{array}{l}\text { - Traženje podrške od udruga u inozemstvu } \\
\text { - Nepostojanje udruge roditelja djece s Williamsovim sindromom }\end{array}$ \\
\hline
\end{tabular}

prvo upoznali majku od koje smo dobili mnoge korisne savjete vezane za operaciju i sindrom. Ma kad imate nekog tko je prošao isto što $i$ vi, suočavanje sa dijagnozom i problemima je bezbolnije $i$ lakše. Bez njihovih savjeta i ohrabrenja teško bi se nosili sa svim izazovima koji su bili pred nama, tako je bilo od početka sve do sada... "(M1).

Sudionice navode kako im je podrška drugih roditelja važna zbog izmjenjivanja iskustava $\mathrm{i}$ razumijevanja: ,,...Ljudi ne razumiju, netko tko to nije prošao, npr. ja imam dosta mama s kojima se čujem koje imaju tako nešto slično, isto svi razmišljamo, dok neki ljudi koji to nemaju oni to ne razumiju... "(M2). Majke u drugim roditeljima traže pomoć u trenutcima izgubljenosti: ,, ... dosta ste izgubljeni u početku jer ne znate što vas čeka i pokušavate naći nekog tko je to sve već prošao, malo nas je, imamo isti problem, zašto si ne bi pomogli. Ja sam upoznala u zadnjih par godina dosta roditelja..."(M3).

Rezultati našeg istraživanja pokazuju da su roditelji druge djece podrška u vidu razumijevanja i izmjenjivanja iskustava. U istraživanju Scallan i suradnika (2010), roditelji djece s Williamsovim sindromom navode kako im je rođenje djeteta $\mathrm{s}$ Williamsom dalo priliku za nova prijateljstva s drugim roditeljima čija djeca imaju istu dijagnozu ili neke druge teškoće. Rezultati upućuju na to da su roditelji ove djece povezani i da im je od izrazite važnosti imati nekoga s kim se mogu poistovjetiti. No jedna sudionica navodi kako postoje roditelji koji ne žele stupiti u kontakt s drugim roditeljima: „,...No nažalost postoje roditelji koji ne žele stupiti u kontakt jedni s drugima tako da, pitanje je zapravo koliko još ima Williamsa u Hrvatskoj, ima nas malo i nedovoljno komuniciramo... "(M3).

Rezultati ukazuju na različita iskustva podrške od strane zdravstvenih djelatnika, pa su tako prisutna i ona pozitivna, kao što je: zadovoljstvo komunikacijom zdravstvenih djelatnika, ali i ona s kojima sudionice nisu zadovoljne, a koje se opisuju kroz nejasne informacije o zdravstvenim tegobama djeteta, nezadovoljstvo informiranošću zdravstvenih djelatnika o bolesti i nezadovoljstvo odnosom zdravstvenih djelatnika prema roditeljima. Pozitivno iskustvo komunikacije zdravstvenih djelatnika sa sudionicama istraživanja opisuje izjava:

„...Neki zbilja jesu, pogotovo pedijatrija, profesori, genetičari... jedna genetičarka mi je bila velika podrška. Ona dijete zna od samog početka, kad smo mi mame gore koje smo bile po cijeli dan, pa smo znale na pauzu se spustit u međuvremenu dok djeca spavaju, a dok je njoj kraj smjene. Onda je ona znala s nama na klupu sjesti, pa se lijepo porazgovara... “; ,, u bolnici jedna medicinska sestra, s njom sam baš bila super, ono znala sam s njom popričati..."(M2).

Roditelji djece s teškoćama imaju češće kontakte sa zdravstvenim djelatnicima od ostatka populacije, a Cazin i suradnici (2014) naglašavaju važnost 
fleksibilnosti u načinu funkcioniranja zdravstvenih institucija, te da se odnos zdravstvenih djelatnika prema roditeljima i djeci temelji na strpljivoj i empatičnoj komunikaciji.

Roditelji navode i adekvatnu podršku lokalne zajednice, prilikom integracije djece u vrtić: ,,... Na svu sreću naš gradić koliko god je loš po nekim stvarima, divni su za integraciju djece. Moja kćer je pet dana u tjednu po četiri sata uredno u vrtiću, neki put sa asistentom, neki put bez asistenta. Kad se to sve dešavalo i kad sam trebala pomoć za upis... sve je išlo lijepo. Osigurano je da moje dijete i preko ljeta ide u vrtić, makar recimo dok ona nije došla, bila im je praksa da djeca s teškoćama ne budu u vrtiću preko ljeta, zato što je smanjen obim posla i teta pa je onda malo teže... "(M3).

Prisutno je i zadovoljstvo lokalnom zajednicom prilikom integracije djece u školu: ,„... Učiteljica ga je već upoznala i učiteljica kaže da su svi s njim super, jedva čekaju da dođe. Ali to je zato što smo se preselili izvan Hrvatske... "(M2). Inkluzivno obrazovanje primarno se veže uz praksu uključivanja sve djece u odgojno-obrazovne skupine $\mathrm{s}$ ciljem zadovoljavanja njihovih temeljnih potreba bez obzira na razvojne teškoće, talente te socioekonomski status. Inkluzija zahtijeva višu razinu uvažavanja djece s teškoćama u razvoju, tretira ih kao potpuno ravnopravne sudionike u odgojnoobrazovnom procesu unutar kojeg je osigurana permanentna individualna pomoć u situacijama kada je neophodna (Mikas i sur., 2012). Na taj način djeci s teškoćama pružen je osjećaj ravnopravnosti, a kod zdrave djece potiče se razvoj tolerancije i prihvaćanje različitosti od prvih godina života. Sudionice našeg istraživanja ističu i zadovoljstvo podrškom drugih stručnjaka, osobito stručnjaka edukacijsko rehabilitacijskog profila, logopeda i defektologa:

„...Stalno ju ambulantno vodimo na terapije kod logopeda i defektologa... “(M1); ,....Ona ide jadan puta tjedno na fizikalnu terapiju, jedan puta tjedno na radnu terapiju i idemo na plivanje. Logopeda imamo i privatno i kod nas preko zdravstvenog... " (M3). Ističu njihovu zainteresiranost dijagnozom: „,...kad je ona odlazila na kontrolu kažem da je Williams, onda se oni svi revno pripreme da znaju šta ja pričam, a ponekad nisu znali ništa o ovoj rijetkoj bolesti... Doktorica je tražila ispred mene po literaturi i nije ništa našla, sjela se žena fino ispred mene i kaže meni majci djeteta molim vas objasnite mi što znači taj sindrom i kako se očituje kod vašeg djeteta... "(M3). Navedene izjave ocrtavaju roditeljska iskustva s formalnom podrškom, te donose primjere pozitivne prakse u sustavu zdravlja koja je obilježena otvorenošću medicinskog osoblja za kontakt i podršku roditeljima.

Sudionice također navode adekvatnu podršku od strane sustava socijalne skrbi; roditelji ističu zadovoljstvo podrškom od strane Centra za socijalnu skrb, naglašavajući kako nisu imali poteškoća prilikom ostvarivanja prava:,,...mi nismo imali nikakvih problema sa Centrom, kada smo ustanovili dijagnozu kontaktirali smo Centar, nakon toga je provedeno vještačenje i priznato joj pravo na osobnu invalidninu, koje i sada koristi..."(M1). Formalna uloga centara za socijalnu skrb uključuje savjetovanje, pružanje podrške te pravovremenog informiranja o pravima i uslugama koje roditelj može ostvariti po osnovni djeteta i životnih okolnosti. Ovdje nam se čini bitnim istaknuti iskustvo sudionice koja se odselila nedavno iz Hrvatske $u$ inozemstvo. Izjava pokazuje razliku u praksi formalne podrške u zapadnoj Europi i dok je obitelj živjela u Hrvatskoj:

„....mi kad smo se obratili njima u jednu ustanovu, oni su nama sve sami odmah riješili. Poštom su nam poslali karticu za osobni invaliditet, poslali su nam papir koji smo trebali ispuniti za pokaz, bez obzira što po njega kombi dolazi. Meni su godišnju kartu dali metrom i vlakom, da se on može vozit, i da ga bilo tko može uzet $i$ u pratnji s njim izaći u javni prijevoz, i čim pokaže tu kartu, može se vozit besplatno. Sve sam to dobila automatski. Ja sam sad dobila status njegovateljice, te mi se uplaćuju doprinosi za mirovinu. I danas sutra ja ću moći mirovinu dobit. I još je dijete dobilo 316,00 eura novčane pomoći, koje ja primam kao njegov njegovatelj. Čak ga obilaze dva puta godišnje $i$ provjeravaju vodi li se briga o njemu. Dobili smo $i$ odobrenje za angažiranje druge osobe ako ja želim otići na godišnji odmor ili nešto drugo obaviti onda mogu za te dodatne novce angažirati treću osobu. I onda osoba koju sam angažirala ispuni formular $i$ dobije sredstva za čuvanje moga djeteta. Ovdje je proces vještačenja humaniji pa kad smo predali te papire, meni je dolazila stručna osoba tu u stan, ja 
dijete nisam nigdje morala vodila... “(M2). Iz ove izjave jasno se vidi dostupnost i pravovremenost formalne podrške za dijete koju trebaju i obitelji u Hrvatskoj.

Druga strana iskustava sudionica istraživanja ukazuje i na to da su roditelji iskusili neadekvatnu podršku od strane zdravstvenih djelatnika i navode tri područja koja su izvor njihovog nezadovoljstva. Roditelji najprije navode kako su nezadovoljni informiranošću zdravstvenih djelatnika o bolesti:

„....prvi put je neonatologica u rodilištu nešto profrfljala, ali nije ništa konkretno rekla o dijagnozi moga djeteta... “ (M3); ,...Baš da je znala ne vjerujem, mislim da mi je rekla da je srela takve djece, ali sad da su pretjerano znali, nisu, pa ni dan danas neki doktori nisu upućeni u to... prolistaju na Internetu... " (M2).

Zatim ističu nezadovoljstvo dobivenim informacijama od strane zdravstvenih djelatnika: „,...Od liječnika kardiologa i genetičara smo dobili osnovne informacije o sindromu, liječnici nam daju šture informacije o zdravstvenom problemu... " (M1); „,...A s tim ne znam koliko ste vi upoznati s tim našim bolnicama, nitko ništa neće reći. Kad sam ga ja pitala nije mi htio ništa reći, veli ništa vam ne mogu reći, samo ćete ići gore, ona zelena zgrada na Rebru i izvaditi krv i napraviti test... "(M2). Istraživanje Waxler i sur. (2013), pokazalo je da visok udio obitelji (60\%) ima negativne uspomene vezane uz iskustvo saznavanja dijagnoze Williamsovog sindroma, a gotovo polovica sudionika gotovo ništa pozitivno ne povezuje s trenutkom saznavanja dijagnoze. Čimbenici koji utječu na pozitivnije percepcije o iskustvu uključuju dobivanje pisanih informacija o Williamsovom sindromu i savjetovanje od strane genetičara. Gotovo četvrtina sudionika izrazila je želju da im se prilikom priopćavanja dijagnoze pruži nada. Roditelji iskazuju nezadovoljstvo odnosom zdravstvenih djelatnika: ,.... I onda je došla sestra i samo mi ga na brzinu donijela i ja sam mu samo lice vidjela, veli mama evo pozdravite se s njim. Ja sam mislila evo, to je zadnje da ga vidim, to me šokiralo... “(M2). Pravo na uživanje najviših ostvarivih zdravstvenih standarda te na pristup i kvalitetu zdravstvenih službi u zajednici u kojoj djeca žive zagarantirani su Konvencijom o pravima djeteta (čl. 24.) i Konvencijom o pravima osoba s invaliditetom (čl. 25.). Unatoč navedenom, rezultati našeg istraživanja pokazuju kako se zdravstvena skrb za djecu s rijetkim bolestima, ali i informiranost zdravstvenih djelatnika i njihov odnos prema roditeljima u izdvojenim primjerima, pokazao neadekvatnim i nekvalitetnim.

Nakon osnutka Jedinstvenog tijela vještačenja, roditelji iskazuju nezadovoljstvo profesionalnošću istog:

„.... On je dole dobio kad smo išli na prvo vještačenje, uvećani doplatak za njegu, jer nije dobio osobnu invalidninu i onda sam ponovno predavala i ponovno je odbijen i predala sam još prije nego što smo išli u inozemstvo i ništa .... "(M2); ,....Mene živcira to jedinstveno tijelo vještačenja, znači svi imamo isti sindrom, svi imamo istu poteškoću, a nemamo svi ista prava... Tak da velim, kod nas dolazi vještačiti nekakva doktorica iz Zagreba koja je u penziji..."(M3).

Roditelji pokušavaju ostvariti prava za svoju djecu i putem udruga. Najčešći ciljevi Udruga su međusobno povezivanje i organiziranje pomoći i podrške oboljelima. Roditelji i djeca s Williamsovim sindromom u Hrvatskoj nemaju svoju udrugu, no iz izjava sudionika istraživanja vidljiva je potreba za istom: ,....Mi smo u stvari imali ideju da bi osnovali Udrugu, koja bi djelovala za širu regiju... "(M3). Sudionice ističu kako su se radi informiranja često okretali udrugama u inozemstvu, no da im one ne mogu pomoći u ostvarivanju prava u Hrvatskoj: „,...Ja sam se većinom okrenula tim udrugama van. Ali što se tiče tih nekih prava i zakona, to vam može pomoć samo netko iz Hrvatske. Šta će mi jedan Amerikanac. Mislim oni tamo imaju kampove, oni imaju bolnice, oni imaju sve prilagođeno Williamsu... “(M3); „....Kad sam ja na internetu čitala, oni imaju Udrugu, idu po izletima, imaju druženje roditelja... "(M2). Sudionice istraživanja ističu važnost udruga u pružanju podrške za dijete $\mathrm{i}$ obitelj, te potrebu za dodatnim aktivnostima $\mathrm{i}$ osnivanjem sekcije usmjerene na Williams sindrom.

\section{2. Život obitelji s rijetkom bolešću}

U Tablici 2. prikazani su rezultati koji daju odgovor na drugo istraživačko pitanje: „Kako roditelji djece s Williams sindromom opisuju život obitelji s rijetkom bolešću?" Ključne teme su slijedeće: emocionalna povezanost članova, senzibili- 
Tablica 2. Tematsko područje: Život obitelji s rijetkom bolešću

\begin{tabular}{|c|c|}
\hline Teme & Kategorije \\
\hline $\begin{array}{l}\text { 1. Emocionalna povezanost i osjećaj bliskosti među } \\
\text { članovima obitelji }\end{array}$ & $\begin{array}{l}\text { - Povezanost članova uže i šire obitelji } \\
\text { - Međusobno podržavanje }\end{array}$ \\
\hline 2. Senzibiliziranost braće i sestara & $\begin{array}{l}\text { - Zaštitnički odnos od strane braće i sestara } \\
\text { - Prihvaćanje i povezanost od strane braće i sestara }\end{array}$ \\
\hline $\begin{array}{l}\text { 3. Teškoće kod roditelja djece s Williamsovim sindromom } \\
\text { vezane uz karakteristike djeteta }\end{array}$ & $\begin{array}{l}\text { - Hipersocijabilnost djeteta } \\
\text { - Hipersenzibilnost djeteta } \\
\text { - Pretjerana zainteresiranost } \\
\text { - Kontakt djeteta s vršnjacima } \\
\end{array}$ \\
\hline $\begin{array}{l}\text { 4. Osobne teškoće kod roditelja djece s Williamsovim } \\
\text { sindromom }\end{array}$ & $\begin{array}{l}\text { - Problem usklađivanja uloga } \\
\text { - Život u strahu } \\
\text { - Sažaljenje drugih } \\
\text { - Socijalna izolacija }\end{array}$ \\
\hline
\end{tabular}

ziranost drugih članova obitelji te teškoće vezane uz dijagnozu djeteta.

Život s djetetom s Williamsovim sindromom jedinstveno je zajedničko iskustvo i može utjecati na sve aspekte obiteljskog funkcioniranja. Može proširiti horizonte, povećati svijest članovima obitelji o njihovim unutarnjim snagama, dovesti do želje za kvalitetnijim provođenjem slobodnog vremena. Sudionice našeg istraživanja opisuju život s djetetom s Williamsovim sindromom kroz snažniju emocionalnu povezanost i osjećaj bliskosti među članovima obitelji, pri čemu ističu međusobnu povezanost članova uže i šire obitelji. Roditelji navode kako ih je angažman oko djeteta još više povezao:

„,...angažman oko nje nas je još više povezao, ja sam sigurna da je ona svojim karakternim osobinama, koje su specifične za djecu s Williamsom, svojom toplinom i pozitivnošću još više povezala sve nas, članove naše uže i šire obitelji... "(M1); i zbližio: „...Pa ja mislim da je on nas zbližio... “(M2). Zatim navode kako smatraju da su poput svake druge obitelji, ističući da kao i svaka druga obitelj imaju svoje uspone i padove: ,....Ma mi kao i svaka druga obitelj imamo svoje uspone i padove u svakom mogućem smislu, a svi se na drugačiji način nosimo sa svakodnevnim problemima... “(M1).

U istraživanju koje je proveo Bayat (2007), pokazalo se da obitelji obično svoje resurse pronalaze u zajedničkim snagama, postaju ujedinjeni i surađuju jedni s drugima za dobrobit djeteta. Sudionice nadalje navode: ,....Naučilo nas je kako da kvalitetno provodimo zajedničke trenutke $i d a$ jednostavno moramo uživati u svakom danu... " (M1). U istraživanju Scallan i suradnika (2010), roditelji također navode kako ih je rođenje djeteta s Williamsovim sindromom dovelo do toga da promjene pogled na život. Roditelji navode kako ih je ono navelo da ne uzimaju stvari zdravo za gotovo, učinilo ih manje materijalistički i karijeristički, a više obiteljski orijentiranima i povezanim s obitelji.

Rođenje djeteta s Williamsovim sindromom također može imati utjecaj na raspodjelu roditeljevog vremena, dovesti do teškoća kod zadovoljavanja potreba druge djece, utjecati na svakodnevne uloge roditelja, na buduće planove, želje, dovesti do svakodnevnog suočavanja sa strahom i socijalne izolacije. Sudionice našeg istraživanja, opisuju život obitelji s djetetom s Williamsovim sindromom kroz teškoće usklađivanje uloge roditelja: „,...Problem nam je postići ravnotežu između želje da ju što više zaštitimo i pružimo joj odgovarajuću skrb s jedne strane $i$ naravno da pritom vodimo normalan obiteljski i društveni život, da ne zanemarimo potrebe drugog djeteta i partnerski odnos ali... “ (M1); ,,...Treba to sve moći uskladiti, troje djece i posao, a to je nemoguća misija... “(M3).

Zahtjevnost različitih uloga koje se pojavljuju u kontekstu obiteljskog života, uključujući i potrebe druge djece, potrebe supružnika, te obiteljske potrebe, često roditelje djece s teškoćama dovodi do suočavanja s tugom, ljutnjom razočarenjem i drugim kompleksnim emocijama. ${ }^{2}$ Također usklađivanje posla i obitelji mnoge roditelje s malom djecom dovodi do dilema, a kada su u pitanju

2 Preuzeto s Web stranice: The National Academic Press. Educating children with autism. http://www.nap.edu/read/10017/chapter/5 (27.6.2016.). 
roditelji djece s teškoćama u razvoju, istraživanja pokazuju da će ti roditelji rjeđe bitni zaposleni kod privatnika, te je veća vjerojatnost da će raditi sa skraćenim radnim vremenom, zarađivati manje novca, smanjiti radno vrijeme ili uzeti dopust (Freedman i sur., 1995). Roditelji navode kako su potisnuli potrebe druge djece, jer briga o oboljelom djetetu iziskuje vrijeme i pažnju: ,,...Ali moram priznati da često njegove potrebe $i$ želje ostanu u drugom planu... “(M1); „...U početku mislim da smo drugu djecu malo zapostavili jer nisam imala vremena za njih, uglavnom smo se trudili al to nije bilo dovoljno... "(M2). Braća i sestre djece $\mathrm{s}$ teškoćama u razvoju funkcioniraju u okruženju obilježenom roditeljskom podijeljenošću oko brige o zdravlju i funkcioniranju djeteta s teškoćama i njih, te s vremenom razviju svoje mehanizme suočavanja s navedenim (Powell-Smith i Stollar, 1997). Roditelji navode želju za osamostaljenjem djeteta: ,...Ma mi želimo da ona bude što samostalnija jer smatramo da će joj onda kasniji period razvoja i školovanja biti lakši, i nama i njoj..." (M1); ,...Meni je najbitnije učenje i osposobljavanje za samostalni život. Dvanaest godina traje to njihovo školovanje onda će oni vidjet u kojem smjeru, jednog dana će možda moći i osjećat će se vrijednim... "(M2). Iskustvo jedne majke na ovu temu može se predstaviti kroz slijedeću izjavu: ,,... Planiram je dovest do tog da ona zna i slova i brojeve ...neće se upisivati u specijalan program, jer kod nas škola koja ima specijalan program je loša, ima sve dijagnoze u jednoj cjelini i ne možete onda $k$ valitetno radit $i$ sve se to svodi na nizanje perlica, mislim da se time još više nazaduje djecu... " (M3).

Iskustva i dikusije o osamostaljenju djece s teškoćama izazivaju različite, a ponekad i proturječne odgovore od strane roditelja, ovisno o njihovim vizijama i očekivanjima za svoje dijete. Iako svi roditelji žele da njihova djeca žive samostalnim životom, neki su roditelji svjesni da će im trebati konstantna podrška (National disability authority, $2001^{3}$ ). Pri planiranju prijelaza iz adolescencije $u$ odraslu dob ključno je da usluge zadovoljavaju specifične potrebe mlade osobe $\mathrm{s}$ invaliditetom (Henninger i Lounds Taylor, 2014). Sudionice našeg istraživanja također navode kako je život obitelji s djetetom s Williamsovim sindromom doveo do življenja u strahu, vezanom uz samostalnost djeteta pri obavljanju svakodnevnih aktivnosti:

„,...danas je on otišao u školu, ali ja sam u strahu za njega. Evo on je u utorak išao na izlet sa školom i ja sam stalno zvala jel on stigao na vrijeme, jel ga doveo vozač, jer mene je strah, nemam ni u kog povjerenje, imam samo u sebe povjerenje i $u$ kćer. On obično hoće vikendom da ga tata vodi $u$ McDonalds, onda ja mužu strogo kažem prije nego iziđu iz stana, nemoj slučajno dok budeš plaćao da ga pustiš, drži ga na oku da on ne bi otišao. Ja znam da pretjerujem možda ali valjda to sve od tog silnog straha. On spava s nama u sobi, mi smo se za ruke držali, glupo reć osam mu je godina, al Bože moj ja ne mogu promijenit to, sad je on već veliki da bi ja nešto i mijenjala, i ako se budi ja se mislim ajme Bože šta ga sad boli, al sad je velik pa zna i sam reći. Ali npr. ako spava cijelu noć, ja se dignem i stanem kraj njega i gledam jel on diše..."(M2).

„...odmorim se jedino kad odem ova dva dana u tjednu na posao, ali mislim se što je s njim... Uvijek mi je mobitel pored mene u slučaju da se nešto desi i jel mi mobitel zvoni, noge mi se odsjeku... Zato velim i taj moj izlazak, još dok smo dolje bili, muž veli ajde s prijateljicama iziđi na kavu, ja odem, ali to je ono, pričamo mi, sjedimo, pijemo kavu, zezamo se, ali to je sve ono ko na iglama što bi rekli. Cijeli život u strahu, ne može se čovjek toliko ni opustit koliko bi, kad znam šta mi je kući, kad znam da može napravit glupost neku... " (M2). Roditelji u ovim izjavama ističu strah koji ih dovodi do socijalne izolacije. Boyd (2002) navodi kako majke djece s teškoćama provode značajno manje vremena u rekreacijskim i sportskim aktivnostima, za razliku od majki čija su djeca urednog zdravlja. Također navodi manjak sudjelovanja u političkim, socijalnim, intelektualnim i kulturnim aktivnostima koje inače služe kao ublaživači stresa.

\section{Majke navode svakodnevne teškoće vezane uz} karakteristike djeteta $s$ Williamsovim sindromom, ističući hipersocijabilnost djeteta:

„... Ma ona vam zna otrčati u zagrljaj nekom tko joj se nasmije dok šetamo gradom. To zna biti

3 Preuzeto s Web stranice National disability authority: http://nda.ie/Publications/Social-Community/Independent-and-Community-Living-FocusGroup-Consultation-Report/Chapter-Five- The-views-and-experiences-of-parents-of-children-with-disabilities/ (25.5.2016.). 
pomalo neugodno, ali još je mala pa prolazi pod simpatično, biti će problem kad odraste... “(M1); „,Mislim i meni nekad nelagodno bude, ne mogu ja njemu na čelu napisat šta je, ono neki ljudi koji ga prvi put vide pogotovo dole iz sredine iz koje dolazimo, doslovno se ne može ni primijetiti da nešto je, tek kad prođe par minuta, onda ljudi ostanu blijedo i gledaju... Je da mu znam reći, sad kad izlazimo iz zgrade ili idemo u šetnju negdje, upozorim ga prije da ne razgovara sa drugim ljudima, jer on obično zastajkuje i hoće razgovarati, onda ga samo upozorim, molim te možeš pozdravit, al nema razgovora s nepoznatima. Al bez obzira na to upozoravanje on to brzo zaboravi. Pogotovo sad kako smo došli u drugu državu i sad kad iziđe u park da se igra, nije mogao nikako pojmit da ljudi ovdje ne pričaju hrvatski, onda je on pokušavao na hrvatski, pa engleski pa ja mu velim makni se, ispričavam se ljudima... on bez problema ide svima, on se mazi sa svima, razgovara sa svima, nema strah od nepoznatih ljudi. Slatko je to dok je on još mali, ali sta će bit kad odraste, a to rade $i$ kad odrastu, $i$ slatko je kad je netko od familije, a kad je netko strani onda zna biti neugodnosti..."(M2). Baker i sur.(2002) ističu da upravo ponašanje djeteta može predstavljati teškoće s kojima se roditelji teško nose u svakodnevnom životu.

Hipersenzibilnost kod djeteta majke opisuju: „,... Recimo kad se neko rasplače ona plače s njim, jedan dan je jedna djevojčica pala i mala je prestala plakat, a moja kćer je plakala narednih pola sata i nikako je nismo mogli smirit... "(M3). Zatim navode njihovu pretjeranu zainteresiranost: „... I ne smije mu se ništa obećati da će negdje ić, prije nego što ga počnem spremat kažem mu, jer ako mu kažem prije onda je to buđenje po noći, kad će proći noć, kad ide...meni je s njim sve izazov... "(M2). U istraživanju koje su proveli Dimitriou i suradnici (2010), gotovo su svi roditelji (97\%) djece s Williamsovim sindromom naveli čest prekid sna kod njihove djece, buđenje više od dva puta tijekom noći i nemiran san. Majke također navode i teškoće prilikom kontakta djeteta $\mathrm{s}$ vršnjacima: „...Problem je i kontakt s vršnjacima, jer se zbog razlika u motoričkoj ili kognitivnoj sposobnosti ne uklapa i to joj izaziva frustracije i želju da više komunicira s odraslima jer se osjeća zaštićeno... “ (M1); ,....Nije baš da su joj draga mlađa djeca, ona recimo voli od ovog starijeg sina ekipu njegovu iz vrtića... “(M3). Klein-Tasman i Mervis (2003) u svom su istraživanju s roditeljima djece s Williamsovim sindromom došli do zaključaka kako djecu s Williamsovim sindromom karakterizira prepoznatljiv profil ličnosti. Roditelji su izjavili da njihovu djecu karakterizira visoka razina društvenosti, žudnja za interakcijom s drugima, kao i visoka razina napetosti i osjetljivosti. Kada su usporedili djecu s Williamsovim sindromom s drugom djecom s teškoćama u razvoju, mali broj djece pokazao je ove specifične karakteristike. Iz rezultata možemo zaključiti kako su djeca s Williamsovim sindromom vrlo društvena, otvorena i osjetljiva, no kako što su i njihovi roditelji iskazali, ta njihova otvorenost predstavlja teškoću roditeljima i okolini (Papaeliou i sur. 2011).

Naposljetku sudionice ističu senzibiliziranost braće i sestara, naglašavajući zaštitnički odnos od strane braće i sestara, ali i prihvaćanje i povezanost:

„....Naravno da je njena dijagnoza utjecala i na njenog brata. Mislim on se odnosi vrlo zaštitnički $i$ baš ima dosta strpljenja... “ (M1), ,....Imam osjećaj da mu više sluša sestru nego mene kad mu kaže ne smiješ to i broji do tri on prestane, ja mu mogu brojat do tisuću ne prestaje... "(M2).

„....Dosta je mala razlika tak da ovaj, znači stariji sin je četiri godine stariji od nje, a mladi godinu i pol... Tak da jako se dobro slažu, igraju se i gnjave između sebe jedan drugog i ona njih tako, ona se zna neki put izborit za sebe, onda oni njoj popuste zato što je mlađa... “(M3); ,, ...dosta su povezani i od njih neke stvari uči a oni s njim nauče o strpljivosti i razumijevanju, prihvaćaju se...."(M2).

U istraživanju Scallan i suradnika (2010), koje je provedeno među roditeljima čija djeca imaju dijagnozu Williamsovog sindroma, roditelji također navode kako je rođenje djeteta s Williamsovim sindromom imalo pozitivan utjecaj na braću i sestre. Roditelji navode i kako je odrastanje s djetetom s Williamsovim sindromom dovelo do toga da braća i sestre pokazuju više razumijevanja, brige i zrelosti. Braća i sestre često gaje nježne i duboke osjećaje prema bratu ili sestri s teškoćama u razvoju (Burke i Montgomery, 2001; 
Wagner Jakab i sur., 2006). Iz navedenog može se zaključiti da je uloga braće i sestara važna za razvoj djece s Wiliamsovim sindromom kod sudionica ovog istraživanja, te da braća i sestre imaju odnos obilježen bliskošću, igrom i povezanošću u ranoj dobi. Ključni nalazi istraživanja pokazali su da članovi obitelji čine zaštitnu mrežu neformalne podrške, te da je sudionicama istraživanja ključna i pozitivna formalna podrška koja se ogleda kroz razgovor s medicinskim osobljem koji je ispunjen poštovanjem i razumijevanjem prema roditeljima i djetetu. Nadalje pozitivne su strane i dobra integracija u sustav odgoja i obrazovanja te podrška koju imaju od roditelja s djece $\mathrm{s}$ istom dijagnozom. $\mathrm{S}$ druge pak strane, rezultati upućuju na potrebu za snažnijom podrškom roditeljima tijekom procesa postavljanja dijagnoze, priopćavanja dijagnoze i procesa vještačenja. Dodatno, roditeljima nedostaje snažniji kontakt s NGO sektorom i udrugama za djecu s Williamsovim sindrom. Roditelji imaju teškoće vezane uz karakteristike djeteta, koje se nadovezuju i na izazove usklađivanja radne i obiteljske uloge, život u strahu, sažaljenju i izolaciji od okoline.

\section{ZAKLJUČAK}

Obitelji djece s rijetkom bolešću suočavaju se s teškoćama i zahtjevima svakodnevnog života, teškoćama skrbi o djetetu unutar obitelji i od strane lokalne zajednice, koja ponekad ne nudi potrebne usluge. Adekvatna socijalna podrška pomaže roditeljima u poboljšanju kvalitete života, boljoj integraciji djeteta u zajednicu i omogućava roditeljima punu participaciju u različitim životnim ulogama. Iz rezultata istraživanja proizlazi da su roditeljima djece s Williamsovim sindromom izvor podrš- ke članovi njihove uže obitelji te roditelji druge djece s istom dijagnozom, koji im daju potrebne informacije i podršku, ali im nedostaje udruga $u$ Hrvatskoj preko koje bi mogli dolaziti do potrebnih informacija i usluga. Prikazana su iskustva s adekvatnom i neadekvatnom podrškom od strane zdravstvenih djelatnika, ali i primjeri pozitivne prakse u sustavu zdravlja, socijalne skrbi i obrazovanja, kao pružateljima formalne podrške djetetu i obitelji. Majke navode da život s ovom rijetkom bolešću dovodi do veće emocionalne povezanosti i osjećaja bliskosti među članovima obitelji. Uz navedeno rezultati upućuju na svakodnevno suočavanje s teškoćama koje Williamsov sindrom donosi za majke ove djece, a koje se očituju kroz probleme vezane uz usklađivanje uloga, balansiranje oko potreba djeteta s dijagnozom i druge djece, ali i kroz izolaciju od okoline. Majke ističu i specifične karakteristike vezane uz dijete i ovaj sindrom, a koje se odražavaju na svakodnevni život djeteta. Izložene spoznaje rezultat su prvog kvalitativnog istraživanja provedenog u Hrvatskoj, te se ne mogu poopćavati na cjelokupnu populaciju obitelji s djecom s Williamsovim sindromom, no ipak ovim istraživanjem dobio se značajan uvid. Istraživanjem su predstavljena iskustva majki djece s Willimasovim sindromom u svakodnevnom životu i skrbi za dijete, no ostaje prostor za daljnja istraživanja ove populacije. Zaključno, u budućim istraživanjima potrebno je uključiti i stručnjake iz sustava formalne podrške te druge članove obitelji (braću, sestre, očeve, bake i djedove), kako bi se dobila jasnija slika sustava podrške u Hrvatskoj. Longitudinalna istraživanja pružila bi znanstvenicima, a nadasve i praktičarima, uvid u razumijevanje životnog ciklusa djeteta i članova obitelji. 


\section{LITERATURA}

Anderson, M., J.Elliott, E., Zurynski, A.Y. (2013): Australian families living with rare disease: experiences of diagnosis, health services use and needs for psychosocial support. Orphanet Journal of Rare Diseases. 8, 22.

Baker, B.L., Blacher, J., Crnic, K.A., Edelbrock, C. (2002): Behavior Problems and Parenting Stress in Families of ThreeYear-Old Children With and Without Developmental Delays. American Journal on Mental Retardation, 107, 6, 433-444.

Bayat, M. (2007): Evidence of resilience in families of children with autism. Journal of Intellectual Disability Research, $51,9,702-714$.

Boyd, A.B. (2002): Examinig the Relationship Between Stress and Lack of Social Support in Mothers of Children With Autism. Focus on Autism and Other Developmental Disabilities, 17, 4, 207-215.

Brinkmann, S. (2013): Qualitative interviewing. Oxford University Press.

Burke, P., Montgomery, S. (2001): Brothers and sisters: Supporting the siblings of children with disabilities. Practice, 13,1, 27-38.

Cazin, K., Cindrić, Ž., Pišćenec, I. (2014): Roditelji djece s poteškoćama u razvoju; stupanj zadovoljstva suradnjom sa zdravstvenim djelatnicima. Sestrinski glasnik, 19, 1, 178-182.

Creswell, J.W., (2003): Research design, qualitative, quantitative and mixed method approaches, Thousand Oaks: Sage.

Dimitriou, D., Hill, M.C., Joyce, A., Karmiloff-Smith, A. (2010): Characterisation of sleep problems in children with Williams Syndrome. Research in developmental disabilities, 32, 164-169.

Donnai, D., Karmiloff-Smith, A. (2000): Williams Syndrome: From genotype though to the cognitive phenotype. American Journal of Medical Genetics, 97, 2, $164-171$.

Freedman, R.I., Litchfield, L.C., Warfield, M.E. (1995): Families in Society, 76, 507-514.

Henninger N. A., Lounds Taylor, J. (2014): Family Perspectives on a Successful Transition to Adulthood for Individuals with Disabilities. Intellectual and Developmental Disabilities, 52, 2, 98-111.

Hughes, D.A., Tunnage, B., Yeo, S.T. (2005): Drugs for exceptionally rare diseases: do they deserve special status for funding? An International Journal of Medicine. 98: 829-36.

Ivić, S., Mravinac, I. (2005): Jezične teškoće djece s Williamsovim sindromom. Zagreb: Edukacijsko rehabilitacijski fakultet Sveučilišta u Zagrebu.

Janković, J. (1995): Teorijska promišljanja o obitelji. Društvena istraživanja Zagreb, 18-19 (4): 433-449.

Jones, K.L., Smith D.W. (1975): The Williams elfin facies syndrome. A new perspective. The Journal of pediatrics, $86,5,718-723$.

Klein-Tasman, B.P. , Mervis, C.B. (2003): Distinctive Personality Characteristics of 8-,9-,and 10-Year-Olds With Williams Syndrome. Developmental neuropsychology, 23, 1-2, 269-290.

Kole, A., Faurisson, F. (2009): The Voice of 12,000 Patients: Experiences and expecttations of rare disease patients on diagnosis and care in Europe. Posjećeno na: http://www.eurordis.org/publication/voice-12000-patients

Konvencija o pravima osoba s invaliditetom. Narodne novine, 6/07.

Konvencija o pravima djeteta. Narodne Novine - Međunarodni ugovori, 12/93.

Leutar, Z., Oršulić, V. (2014): Povezanost socijalne podrške i nekih aspekata roditeljstva u obiteljima s djecom s teškoćama u razvoju. Zagreb: Pravni fakultet Sveučilišta u Zagrebu.

Leutar, Z., Ogresta, J., Milić Babić, M. (2008): Obitelji osoba s invaliditetom i mreže podrške. Zagreb: Pravni fakultet Sveučilišta u Zagrebu.

Lundy, H.F. (2011): Parental Stress, Socioeconomic Status, Satisfaction with Services, and Family Quality of Life among Parents of Children Receiving Special Education Services. Georgia State University. 
Martinac Dorčić, T. (2008): Razlike između majki i očeva djece s cerebralnom paralizom u rizičnim i zaštitnim faktorima te prilagodbi. Hrvatska revija za rehabilitacijska istraživanja, 44, 2, 63-78.

Martnes, M.A., Wilson, S.J., Reutens, D.C. (2008): Research Review: Williams syndrome: a critical review of the cognitive, behavioral, and neuroanatomical phenotyp. Journal of Child Psychology and Psychiatry, 49, 6, 576-608.

Mervis, C.B., Klein-Tasman, B.P. (2000): Williams syndrome: cognition, personality, and adaptive behavior. Mental Retardation and Developmental Disabilities Research Reviews, 6, 148-158.

Mervis, C.B., Velleman, S.L. (2012): Children with Williams Syndrome: Language, Cognitive, and Behavioral Characteristics and their Implications for Intervention. Perspect. Lang Learn Educ, 18, 3, 98-107.

Metcalfe, K. (1999): Williams syndrome: an update on clinical and molecular aspects. Arch Dis Child, 81, 3, 198-200.

Mikas, D., Roudi, B. (2012): Socijalizacija djece s teškoćama u razvoju u ustanovama predškolskog odgoja. Paediatr Croat, 56, 1, 207-214.

Milas, G. (2005): Istraživačke metode u psihologiji i drugim društvenim znanostima. Jastrebarsko: Naklada Slap.

Milić Babić, M. (2010): Socijalna podrška, obilježja roditelja i djeteta kao odrednice doživljaja roditeljstva. Doktorska disertacija. Zagreb: Pravni fakultet, Studijski centar socijalnog rada.

Ministarstvo zdravlja Republike Hrvatske (2015): Nacionalni program za rijetke bolesti 2015-2020. Vlada Republike Hrvatske.

Papaeliou, C., Polemikos, N., Fryssira, E., Kodakos, A., Kaila, M., Yiota, X., Benaveli, E., Michaelides, C., Stroggilos, V., Vrettopoulou, M. (2011): Behavioural profile and maternal stress in Greek young children with Williams syndrome. Blackwell Publishing Ltd, Child: care, health and development.

Powell-Smith, K.A., Stollar, S.A. (1997): Families of children with disabilities. University of South Florida.

Ritchie J, Lewis J (2003): Qualitative research practice: A guide for social science students and researchers, London: Sage Publications.

Scallan, S., Senior, J., Reilly, C. (2010): Williams Syndrome: Daily Challenges and Positive Impact on the Family. Journal of Applied Research in Intellectual Disabilities, 24, 181-188.

Srivastava, A., Thomson, S. B. (2009): Framework analysis: A qualitative methodology for applied policy research. Journal of Administration \& Governance, 4,2, 72-78.

Škes, M. (2015): Živjeti s rijetkom bolesti. Dostupno na http://www.stampar.hr/hr/zivjeti-s-rijetkom-bolestimedunarodni-dan-rijetkih-bolesti-28-veljace-2015

Udwin, O., Davies, M., Howlin, P., Stinton, C. (2007): Adults with Williams syndrome, guidelines for families and professionals. The Williams Syndrome Foundation.

Žižak, A., Koller-Trbović, N., Jeđud Borić, I., Maurović, I., Mirosavljević, A., Ratkajec Gašević, G. (2012): Što nam djeca govore o udomiteljstvu-Istraživanje dječje perspektive udomiteljstva u Hrvatskoj s preporukama za unapređenje. Zagreb: UNICEF.

Wagner Jakab, A. (2008): Obitelj-sustav dinamičnih odnosa u interakciji. Hrvatska revija za rehabilitacijska istraživanja, $44,2,119-128$.

Wastfelt, M., Fadeel, B., Henter, J.I. (2006): A journey of hope: lessons learned from studies on rare diseases and orphan drugs. Journal of Internal Medicine, 260, 1, 1-10.

Waxler, J.L., Cherniske, E.M., Dieter, K., Herd, P., Pober, B.R. (2009): Williams syndrome: a multidisciplinary approach to care. Pediatr Ann, 38, 8, 456-63.

Waxler, J.L., Cherniske, E.M., Dieter, K., Herd, P., Pober, B.R. (2013): Hearing from parents: the impact of receiving the diagnosis of Williams syndrome in their child. American Journal for medical genetics, 161A, 3, 534-541.

White, N., Hastings, R.P. (2004): Social and Professional Support for Parents of Adolescents with Sever Intellectual Disabilities. Journal of Applied Research in Intellectual Disabilities, 17, 1, 181-190. 


\title{
EXPERIENCE OF MOTHERS OF CHILDREN WITH WILLIAMS SYNDROME
}

\begin{abstract}
Williams syndrome is a rare genetic neurodevelopmental disorder, and the present study aimed to gain insights into the life experiences of affected children and the support available to them. This qualitative study is the first to explore the experiences of mothers of children with Williams syndrome in Croatia, which is home to 11 such children based on unofficial data. Thematic analysis of semi-structured interviews showed that mothers experienced in increase in emotional connection and intimacy among family members after the birth of the affected child, and that they received support from their husbands, other family members and other parents of affected children. At the same time, the mothers reported difficulties such as adjusting and harmonizing life roles, social isolation, lack of understanding from other people and daily care for the child. These findings may encourage and guide future research on improving the quality of life of children and adults suffering from rare diseases.
\end{abstract}

Key words: rare diseases, parenthood, Williams syndrome 